\title{
PHYSICAL AND CHEMICAL RESEARCH OF PROCESSES OF SALT FORMATION IN THE WATER OF BALKHASH LAKE
}

\author{
Myrzabay Dzhetimov, Erlan Andasbayev, Ilias Esengabylov, Sayle Koyanbekova, Erkyn \\ Tokpanov, Zhetysu State University named after I. Zhansugurov, barieva010@ mail.ru
}

\begin{abstract}
In recent years about 5.04 million tons of salts a year arrive down the River Ili to Balkhash Lake. Using water of the Ili River for filling the Kapchagaisky reservoir reduced volume of arriving water from the river to $2 / 3$ and decreased level of the Lake. It causes mineralization, which advances forecasts. Complex research of influence of the Ili River on the current state of salt formation in Balkhash Lake is needed as well as hydrochemical research of the water area of Balkhash Lake and the Ili River. In our study the chemical analysis of the qualitative and quantitative characteristics of water with use of classical and physical and chemical methods of the analysis, such as, nuclear and absorbing, roentgen fluorescence spectrometry and crystal and optical analysis was realized. It is established that crystallization of salts begins with calcium carbonate in the form of aragonite; crystals of nesquehonite join this process, and in deposit the main carbonate of magnesium drops out. Processes of metamorfization with participation of ions of carbonate, hydro carbonate and calcium, are bringing calcite sedimentation. They occur everywhere, but processes with participation of magnesium ions are bringing magnesite or dolomite sedimentation only in extreme east stretch of the Lake. In saturated solutions of carbonates there is an increase in ions of potassium in sediment. Thus, their quantities increase a little. It is especially sharp for sulfate and sodium chloride in the direction from the west to the east. The calcium carbonate in the firm phase possesses more absorbing ability, than magnesium carbonate, and the presence of ions of potassium at sediment doesn't change structure of the last. At isothermal evaporation of mix of solutions of potassium carbonate with saturated solution of calcium carbonate, and also potassium sulfate with saturated solution of calcium sulfate and the joint sedimentation of potassium is noticed.
\end{abstract}

JEL Classification Numbers: 574.9, DOI: 10.12955/cbup.2013.63

Keywords: mineralization, metamorfization, formation of carbonates, concentration, Balkhash Lake, Kazakhstan

\section{Introduction}

Water resources of Kazakhstan are one of the major factors stimulating the rates of its economic development. Numerous salt lakes on the territory of the republic are the source of natural salts. One of the major continental salt basins of Kazakhstan is Pribalkhashye - district of the Lake of Balkhash (Beremzhanov, 1989).

On the Ecology Chair of Zhetysu State University named after I.Zhansugurov, genesis of natural salts of Pribalkhashya was investigated and rational ways of using sulphatic lakes were proved. 
In literature, there is an absence of a uniform approach to the solution of sediment formation processes in continental reservoirs. This was the reason for starting hydro chemical research on the water area of Balkhash Lake since the summer 2009. Its purpose was specification of modern salt balance of the Lake and development of forecast for prospect.

Studying of hydrochemistry of Balkhash Lake is closely connected with the problem of optimum use of water resources of its basin, including the Lake itself.

\section{Methodology}

The process of carbonates formation is observed in many modern reservoirs, but in Balkhash Lake it is the most intensive (Moon \& Bekturova, 1992).

Continuous inflow of river waters which salt structure includes $\mathrm{Ca}\left(\mathrm{HCO}_{3}\right)_{2}$ and $\mathrm{Mg}\left(\mathrm{HCO}_{3}\right)_{2}$, high concentrations of salts as a result of evaporation, create conditions for displacement in the system of carbonate and calcium balance towards formation of carbonate ions according to the scheme:

$$
\mathrm{Ca}^{2+}+2 \mathrm{HCO}^{3-} \rightarrow \mathrm{CaCO}_{3}+\mathrm{CO}_{2}+\mathrm{H}_{2} \mathrm{O} .
$$

The carbonate system of water of Balkhash Lake was researched repeatedly generally from the point of view of accumulating carbonate combinations in the bottom sediments of the Lake. The question of taking into account this process in salt balance of the Lake is put for the first time by M.Tarasov (Tarasov, 1961).

During the summer 2009 the detailed hydro chemical shooting of the Lake was carried out. We took 206 water samples from 116 points standing from each other at distance of 5-7 km. We took 34 water samples from the Ili River in the mouth area. General chemical water analysis and processing of the received results was realized with standard methods in hydrochemistry.

From hydro chemical point of view, Balkhash Lake is a unique reservoir; mineralization and the ratio of the main ions in Lake water naturally change its length from the west to the east. By long-term observations (1985-2009) it was established that in the southwest part of the Lake mineralization fluctuates from 0.65 to $1.42 \mathrm{~g} / \mathrm{l}$, and in the most east stretch - from 4.80 to $5.76 \mathrm{~g} / \mathrm{l}$ (Snegiryova, 1970).

Comparison of some prognosis estimations with actual data shows that growth of water mineralization in recent years considerably outgoes in intensity the prognosis values (see Table 1).

\begin{tabular}{|c|c|c|c|c|c|c|c|c|}
\hline \multirow{4}{*}{ Year } & \multicolumn{8}{|c|}{ Organization } \\
\hline & \multicolumn{2}{|c|}{ KazNIGMI } & \multicolumn{2}{|c|}{ ZHGU } & \multicolumn{2}{|c|}{ GGI } & \multicolumn{2}{|c|}{ KazGP } \\
\hline & $\begin{array}{l}\text { Western } \\
\text { Balkhash }\end{array}$ & $\begin{array}{c}\text { East } \\
\text { Balkhash }\end{array}$ & $\begin{array}{l}\text { Western } \\
\text { Balkhash }\end{array}$ & $\begin{array}{c}\text { East } \\
\text { Balkhash }\end{array}$ & $\begin{array}{l}\text { Western } \\
\text { Balkhash }\end{array}$ & $\begin{array}{c}\text { East } \\
\text { Balkhash }\end{array}$ & $\begin{array}{l}\text { Western } \\
\text { Balkhash }\end{array}$ & $\begin{array}{c}\text { East } \\
\text { Balkhash }\end{array}$ \\
\hline & \multicolumn{2}{|c|}{ Prognosis } & \multicolumn{2}{|c|}{ actual } & \multicolumn{2}{|c|}{ actual } & & \\
\hline 1985 & & 2.53 & & & & & & \\
\hline 1989 & & & & & & & 1.97 & 2.63 \\
\hline 1995 & 1.53 & 3.61 & & & & & 1.44 & 2.77 \\
\hline 1999 & & 3.44 & & & 1.9 & 4.4 & 1.56 & \\
\hline 2005 & & 3.73 & 1.85 & 4.58 & & & & \\
\hline
\end{tabular}


CBU INTERNATIONAL CONFERENCE ON INTEGRATION AND INNOVATION IN SCIENCE AND EDUCATION

\begin{tabular}{|l|l|l|l|l|l|l|l|l|}
\hline 2009 & 4.17 & 2.76 & 6.23 & & & & \\
\hline 2011 & 5.12 & 3.05 & 6.78 & & & & \\
\hline
\end{tabular}

According to its structure water belongs to sulphatic class of sodium group with increased content of chlorides. With mineralization growth in length of the Lake the relative contents of ions of $\mathrm{HCO}^{3-}$, $\mathrm{CO}_{3}{ }^{2-}, \mathrm{CaI}^{+}$decreases, but the contents of ions of $\mathrm{Cl}^{-}, \mathrm{SO}_{4}{ }^{2-}, \mathrm{Mg}^{2+}, \mathrm{Na}^{+}, \mathrm{K}^{+}$increases (Table 2).

\begin{tabular}{|c|c|c|c|c|c|c|c|c|}
\hline \multirow{2}{*}{$\begin{array}{l}\text { Hydro- } \\
\text { chemical } \\
\text { area }\end{array}$} & $\mathrm{Ca}^{2+}$ & $\mathrm{Mg}^{2+}$ & $\mathrm{Na}^{+}+\mathrm{K}^{+}$ & $\mathrm{HCO}_{3}^{-}$ & $\mathrm{CO}_{3}^{2-}$ & $\mathrm{SO}_{4}^{2-}$ & $\mathrm{Cl}^{-}$ & \multirow{2}{*}{$\sum \mathrm{Mg} / \mathrm{l}$} \\
\hline & \multicolumn{7}{|c|}{$1 / \mathrm{z}(\mathrm{C}) \mathrm{mmol} / \mathrm{l} \mathrm{m} / \mathrm{l}$} & \\
\hline 1 & $\begin{array}{l}2.17 \\
43.4\end{array}$ & $\begin{array}{l}7.80 \\
94.4\end{array}$ & $\begin{array}{l}11.83 \\
295.7\end{array}$ & $\begin{array}{c}4.60 \\
280.7\end{array}$ & $\begin{array}{l}0.80 \\
24.0\end{array}$ & $\begin{array}{c}10.6 \\
508.8\end{array}$ & $\begin{array}{c}5.80 \\
206.0\end{array}$ & 1453 \\
\hline 2 & $\begin{array}{l}2.05 \\
41.1\end{array}$ & $\begin{array}{l}7.15 \\
86.9\end{array}$ & $\begin{array}{l}12.60 \\
315.0\end{array}$ & $\begin{array}{c}4.30 \\
262.4\end{array}$ & $\begin{array}{l}0.80 \\
24.0\end{array}$ & $\begin{array}{c}11.5 \\
552.7\end{array}$ & $\begin{array}{c}5.20 \\
184.2\end{array}$ & 1466 \\
\hline 3 & $\begin{array}{l}1.84 \\
36.9\end{array}$ & $\begin{array}{l}10.40 \\
126.1\end{array}$ & $\begin{array}{l}18.68 \\
467.0\end{array}$ & $\begin{array}{c}4.92 \\
300.7\end{array}$ & $\begin{array}{l}1.44 \\
43.2\end{array}$ & $\begin{array}{c}16.3 \\
783.6\end{array}$ & $\begin{array}{c}7.90 \\
281.0\end{array}$ & 2038 \\
\hline 4 & $\begin{array}{l}1.71 \\
34.3\end{array}$ & $\begin{array}{l}11.90 \\
145.2\end{array}$ & $\begin{array}{l}24.45 \\
611.3\end{array}$ & $\begin{array}{c}5.28 \\
322.5\end{array}$ & $\begin{array}{l}1.97 \\
59.1\end{array}$ & $\begin{array}{c}18.9 \\
905.9\end{array}$ & $\begin{array}{l}11.10 \\
393.1\end{array}$ & 2471 \\
\hline $\begin{array}{r}\text { Western } \\
\text { Balkhash }\end{array}$ & $\begin{array}{l}1.94 \\
38.9\end{array}$ & $\begin{array}{c}9.30 \\
113.1\end{array}$ & $\begin{array}{l}16.58 \\
414.5\end{array}$ & $\begin{array}{c}4.77 \\
291.5\end{array}$ & $\begin{array}{l}1.25 \\
37.5\end{array}$ & $\begin{array}{c}14.3 \\
687.7\end{array}$ & $\begin{array}{c}7.50 \\
266.0\end{array}$ & 1849 \\
\hline 5 & $\begin{array}{l}1.16 \\
23.2 \\
\end{array}$ & $\begin{array}{l}17.04 \\
207.2 \\
\end{array}$ & $\begin{array}{r}36.90 \\
922.3 \\
\end{array}$ & $\begin{array}{c}7.47 \\
456.1 \\
\end{array}$ & $\begin{array}{l}1.96 \\
59.0 \\
\end{array}$ & $\begin{array}{c}25.9 \\
124.7 \\
\end{array}$ & $\begin{array}{l}19.70 \\
700.4 \\
\end{array}$ & 3615 \\
\hline 6 & $\begin{array}{l}0.99 \\
20.0\end{array}$ & $\begin{array}{l}18.50 \\
224.6\end{array}$ & $\begin{array}{l}40.84 \\
102.1\end{array}$ & $\begin{array}{c}7.96 \\
485.9\end{array}$ & $\begin{array}{l}2.27 \\
68.2\end{array}$ & $\begin{array}{c}28.2 \\
135.4\end{array}$ & $\begin{array}{l}21.90 \\
776.2\end{array}$ & 3950 \\
\hline 7 & $\begin{array}{l}0.99 \\
19.8\end{array}$ & $\begin{array}{l}22.80 \\
277.2\end{array}$ & $\begin{array}{l}52.40 \\
131.0\end{array}$ & $\begin{array}{c}9.55 \\
583.3\end{array}$ & $\begin{array}{c}3.44 \\
103.2\end{array}$ & $\begin{array}{l}34.80 \\
167.3\end{array}$ & $\begin{array}{l}28.40 \\
100.9\end{array}$ & 4976 \\
\hline 8 & $\begin{array}{l}0.71 \\
14.2 \\
\end{array}$ & $\begin{array}{l}26.80 \\
314.0 \\
\end{array}$ & $\begin{array}{c}61.6 \\
153.9 \\
\end{array}$ & $\begin{array}{c}10.79 \\
659 \\
\end{array}$ & $\begin{array}{c}4.20 \\
126.0 \\
\end{array}$ & $\begin{array}{c}41.0 \\
197.1 \\
\end{array}$ & $\begin{array}{l}32.10 \\
114.0 \\
\end{array}$ & 5763 \\
\hline $\begin{array}{c}\text { East } \\
\text { Balkhash }\end{array}$ & $\begin{array}{l}0.96 \\
19.3\end{array}$ & $\begin{array}{l}21.03 \\
255.7\end{array}$ & $\begin{array}{l}47.92 \\
119.8\end{array}$ & $\begin{array}{l}8.94 \\
546\end{array}$ & $\begin{array}{l}2.97 \\
89.1\end{array}$ & $\begin{array}{c}32.5 \\
156.1\end{array}$ & $\begin{array}{l}15.50 \\
906.5\end{array}$ & 4576 \\
\hline $\begin{array}{c}\text { Average } \\
\text { value }\end{array}$ & $\begin{array}{l}1.45 \\
29.1\end{array}$ & $\begin{array}{l}15.20 \\
184.4\end{array}$ & $\begin{array}{l}32.20 \\
806.5\end{array}$ & $\begin{array}{c}6.86 \\
418.7 \\
\end{array}$ & $\begin{array}{l}2.11 \\
63.3\end{array}$ & $\begin{array}{l}23.4 \\
1124\end{array}$ & $\begin{array}{l}16.50 \\
586.2\end{array}$ & 3212 \\
\hline
\end{tabular}

Comparing values of chlorine factors of some ions (Table 3, Figure1) it is visible that in the Lake there are processes in which ions of calcium, magnesium, carbonate, hydro carbonate as well as sulfate ions take notable part. However, the processes proceeding in different places of the Lake are not of the same type. Metamorphization processes with participation of carbonate, hydro carbonate ions and calcium ions, bringing to calcite sedimentation, occur everywhere, but processes with participation of magnesium ions, bringing to sedimentation of magnesite or probably dolomite, occur only in extreme east stretch of the Lake. 
CBU INTERNATIONAL CONFERENCE ON INTEGRATION AND INNOVATION IN SCIENCE AND EDUCATION

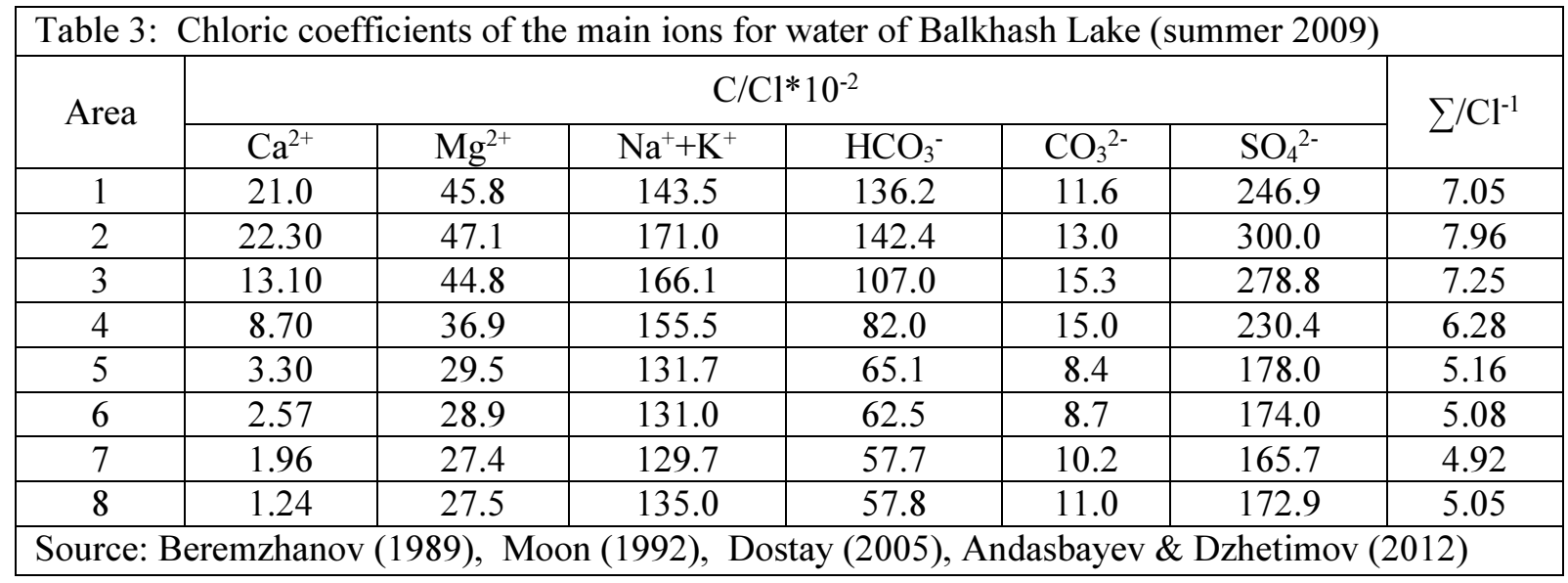

Figure 1: Change of value of chloric coefficients of some ions for water of Balkhash Lake

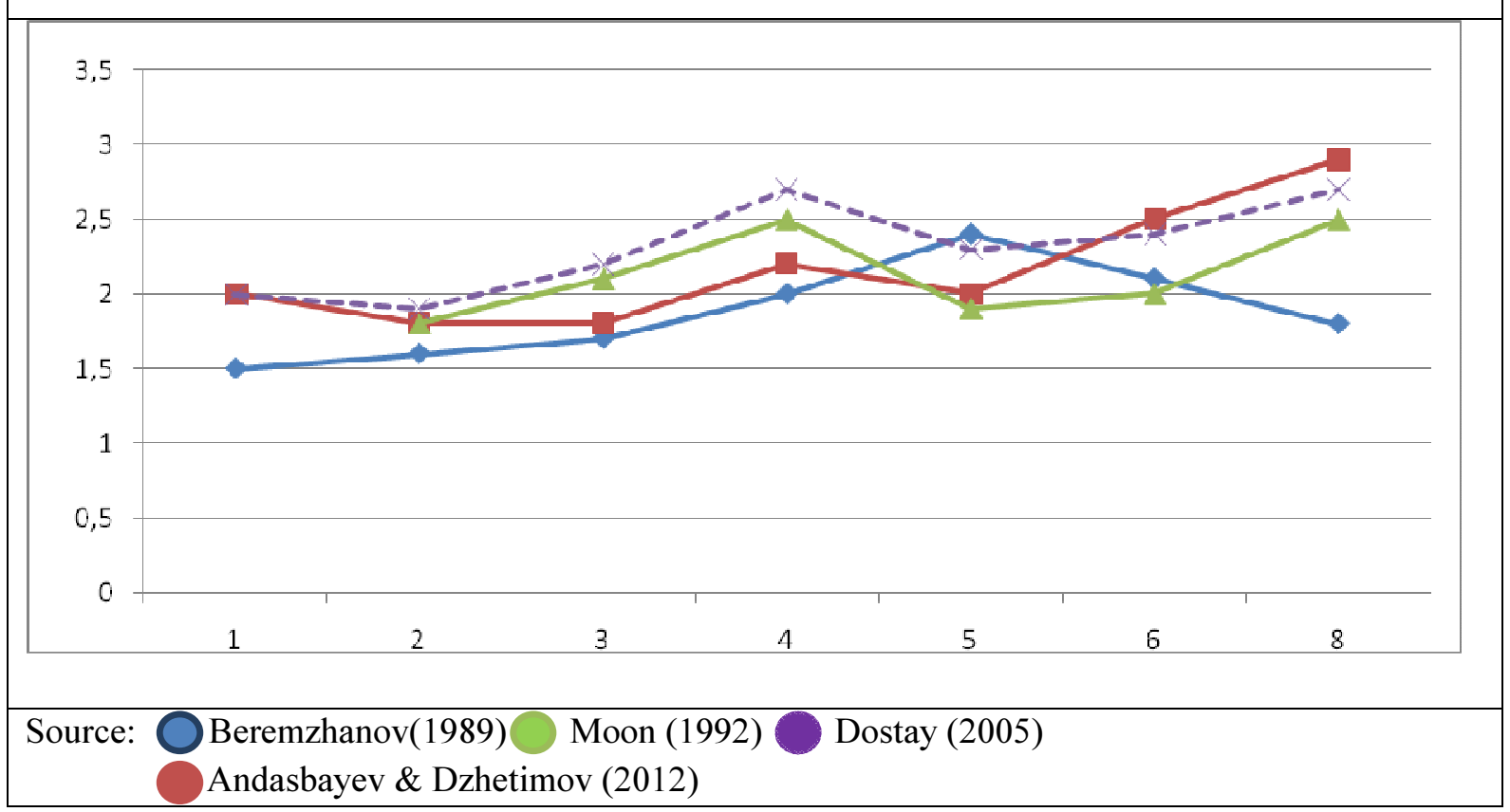

These conclusions confirm opinion of Tarasov (1961) and others about sedimentation of carbonates from Balkhash water, but there is dissimilarity of the processes proceeding in the western and eastern parts of the Lake (Abrosov, 1983). In this connection analogy in change of concentration of the sum of hydro carbonates and carbonates on the one hand, and the sum of calcium and magnesium on another hand (Table 4, Figure 2) is very significant.

\begin{tabular}{|c|c|c|c|c|c|c|c|c|c|c|c|}
\hline 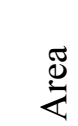 & & & Cont & $t$ of io & $1 / z(C$ & $\mathrm{nmol} / \mathrm{l}$ & & & $\begin{array}{l}\text { Carbo } \\
\text { and re }\end{array}$ & ted & $\mathrm{Cl}^{-}$ \\
\hline Z & $\mathrm{Cl}^{-}$ & $\mathrm{SO}_{4}{ }^{2-}$ & $\mathrm{HCO}_{3}{ }^{-}$ & $\mathrm{CO}_{3}{ }^{2-}$ & $\mathrm{Ca}^{2+}$ & $\mathrm{Mg}^{2+}$ & $\mathrm{Na}^{+}, \mathrm{K}^{+}$ & $\Sigma$ & $\begin{array}{c}1 / \mathrm{z} \\
\mathrm{mmol} / 1\end{array}$ & $\begin{array}{l}\% \\
\sum\end{array}$ & $\mathrm{SO}_{4}{ }^{2-}$ \\
\hline 1 & $\begin{array}{l}5.4 \\
5.4\end{array}$ & $\begin{array}{l}10.1 \\
10.1\end{array}$ & $\begin{array}{c}4.48 \\
-\end{array}$ & $\begin{array}{c}0.80 \\
-\end{array}$ & 2.12 & $\begin{array}{l}7.57 \\
4.41\end{array}$ & $\begin{array}{l}11.23 \\
11.23\end{array}$ & $\begin{array}{l}41.8 \\
31.2\end{array}$ & 10.5 & 25.2 & 0.5 \\
\hline
\end{tabular}


CBU INTERNATIONAL CONFERENCE ON INTEGRATION AND INNOVATION IN SCIENCE AND EDUCATION

\begin{tabular}{|c|c|c|c|c|c|c|c|c|c|c|c|}
\hline 2 & $\begin{array}{l}5.4 \\
5.4\end{array}$ & $\begin{array}{l}11.2 \\
11.2\end{array}$ & $\begin{array}{c}4.37 \\
-\end{array}$ & $\begin{array}{c}0.82 \\
-\end{array}$ & 1.97 & $\begin{array}{l}7.26 \\
4.04\end{array}$ & $\begin{array}{l}12.58 \\
12.58\end{array}$ & $\begin{array}{l}43.6 \\
33.2\end{array}$ & 10.3 & 23.7 & 0.4 \\
\hline 3 & $\begin{array}{l}7.8 \\
7.8\end{array}$ & $\begin{array}{l}15.3 \\
15.3\end{array}$ & 4.83 & 1.36 & 1.8 & $\begin{array}{l}9.90 \\
5.52\end{array}$ & $\begin{array}{l}17.64 \\
17.64\end{array}$ & $\begin{array}{l}59.7 \\
46.3\end{array}$ & 12.3 & 20.7 & 0.5 \\
\hline 4 & $\begin{array}{l}10.2 \\
10.2\end{array}$ & $\begin{array}{l}17.3 \\
17.3\end{array}$ & $\begin{array}{c}5.06 \\
-\end{array}$ & $\begin{array}{c}1.91 \\
-\end{array}$ & 1.68 & $\begin{array}{l}11.4 \\
6.63\end{array}$ & $\begin{array}{l}21.39 \\
21.39\end{array}$ & $\begin{array}{l}69.0 \\
55.5\end{array}$ & 13.4 & 19.5 & 0.5 \\
\hline 5 & $\begin{array}{l}19.1 \\
19.1\end{array}$ & $\begin{array}{l}25.5 \\
25.5\end{array}$ & $\begin{array}{c}7.42 \\
-\end{array}$ & $\begin{array}{c}2.07 \\
-\end{array}$ & 1.17 & $\begin{array}{l}16.8 \\
8.52\end{array}$ & $\begin{array}{l}36.13 \\
36.13\end{array}$ & $\begin{array}{c}108.0 \\
0 \\
89.3\end{array}$ & 18.9 & 17.5 & 0.7 \\
\hline 6 & $\begin{array}{l}22.1 \\
22.1\end{array}$ & $\begin{array}{l}28.8 \\
28.8\end{array}$ & $\begin{array}{c}8.00 \\
-\end{array}$ & $\begin{array}{c}2.31 \\
-\end{array}$ & 1.00 & $\begin{array}{l}18.5 \\
9.19\end{array}$ & $\begin{array}{l}41.76 \\
41.76\end{array}$ & $\begin{array}{c}122.5 \\
1 \\
101.9 \\
0\end{array}$ & 20.6 & 16.8 & 0.7 \\
\hline 7 & $\begin{array}{l}28.0 \\
28.0\end{array}$ & $\begin{array}{l}34.1 \\
34.1\end{array}$ & $\begin{array}{c}9.63 \\
-\end{array}$ & $\begin{array}{c}3.36 \\
-\end{array}$ & 0.96 & $\begin{array}{l}22.3 \\
10.3\end{array}$ & $\begin{array}{l}51.87 \\
51.87\end{array}$ & $\begin{array}{c}150.3 \\
6 \\
124.3 \\
8\end{array}$ & 25.9 & 17.2 & 0.8 \\
\hline 8 & $\begin{array}{l}32.8 \\
32.8\end{array}$ & $\begin{array}{l}41.2 \\
41.2\end{array}$ & $\begin{array}{c}10.73 \\
-\end{array}$ & $\begin{array}{c}0.68 \\
-\end{array}$ & 0.68 & $\begin{array}{l}26.0 \\
15.6\end{array}$ & $\begin{array}{l}62.31 \\
62.31\end{array}$ & $\begin{array}{c}176.9 \\
8 \\
152.0 \\
5\end{array}$ & 25.9 & 14.6 & 0.8 \\
\hline
\end{tabular}

Figure 2: Change of value of concentration of ionic composition of water of Balkhash Lake in its length

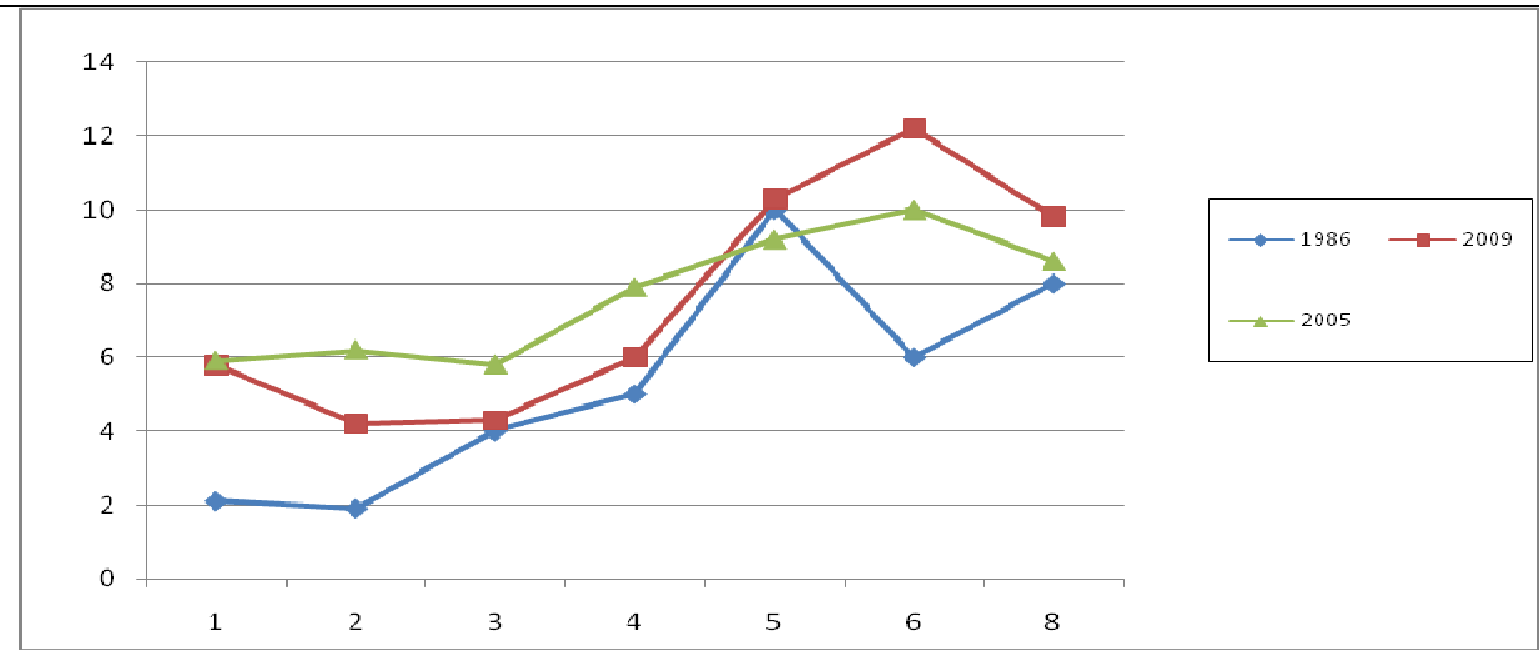

Source: Beremzhanov (1989), Dostay (2005), Andasbayev \& Dzhetimov (2012)

If carbonates didn't participate in sedimentation process, their contents, as well as the content of chlorine ions, should increase in the 8th hydro chemical area (Burlyu-Tyubinsky stretch) approximately six times and are about $32.0 \mathrm{mmol} / \mathrm{l}$. The observed content of carbonates in this stretch is $10.73 \mathrm{mmol} / \mathrm{l}$, that is $21.27 \mathrm{mmol} / \mathrm{l}$ less than it would be observed in the specified case. Similar calculation for the sum of calcium and magnesium gives $31.46 \mathrm{mmol} / \mathrm{l}$, that is close figure.

If we compare ionic composition of the Lake water with the same structure, but minus calcium and magnesium containing in it, (Table 4), it is possible to see that the absolute total quantity of carbonates 
of calcium and magnesium grows from 10.56 in the west to $25.93 \mathrm{mmol} / 1$ in the east (increase by 2.5 times). However their relative contents in general concentration of salts in the same direction fall almost in two times. In another words in the direction from the west to the east Balkhash water unites according to the content of carbonate combinations and first of all calcium as a result of sedimentation that is convincingly confirmed by the data of Table 4 . If carbonic calcium is present at all areas of the Lake, carbonic magnesium is absolutely absent in the water of the western stretch, appearing only in the eastern half of the reservoir. Here as approaching the eastern part of the Lake, the tendency to increase in the content of this salt is clearly visible. All other salts $\left(\mathrm{Mg}\left(\mathrm{HCO}_{3}\right)_{2}, \mathrm{MgSO}_{4}, \mathrm{Na}_{2} \mathrm{SO}_{4}\right.$, $\mathrm{NaCl}, \mathrm{KCl}$ ) are present in the Lake water everywhere (Table 5). Thus their quantity increases a little, especially sharp for sulfate and sodium chloride in the direction from the west to the east.

\begin{tabular}{|c|c|c|c|c|c|c|c|}
\hline \multicolumn{8}{|c|}{$\begin{array}{l}\text { Table 5: Average salt composition of water of Balkhash Lake in hydro chemical areas (mmol/1, \% } \\
\text { from the sum of salts) }\end{array}$} \\
\hline $\begin{array}{c}\text { Hydro- } \\
\text { chemical areas }\end{array}$ & $\mathrm{CaCO}_{3}$ & $\mathrm{Ca}\left(\mathrm{HCO}_{3}\right)_{2}$ & $\mathrm{MgCO}_{3}$ & $\mathrm{Mg}\left(\mathrm{HCO}_{3}\right)_{2}$ & $\mathrm{MgSO}_{4}$ & $\mathrm{Na}_{2} \mathrm{SO}_{4}$ & $\mathrm{NaCl}+\mathrm{KCl}$ \\
\hline 1 & $0.80 / 3.6$ & $1.37 / 6.3$ & - & $3.23 / 14.8$ & $4.57 / 20.9$ & $6.03 / 27.6$ & $5.80 / 26.6$ \\
\hline 2 & $0.80 / 3.6$ & $1.25 / 5.7$ & - & $3.05 / 13.9$ & $4.10 / 18.8$ & $7.35 / 33.7$ & $5.25 / 24.1$ \\
\hline 3 & $1.44 / 4.6$ & $0.40 / 1.3$ & - & $4.52 / 14.6$ & $5.88 / 19.0$ & $10.42 / 33.7$ & $8.26 / 26.71$ \\
\hline 4 & $1.71 / 4.5$ & - & $0.26 / 0.68$ & $5.28 / 13.9$ & $6.36 / 16.7$ & $12.54 / 32.9$ & $1.91 / 31.3$ \\
\hline $\begin{array}{l}\text { Comparison } \\
\text { Western } \\
\text { Balkhash }\end{array}$ & $1.25 / 4.5$ & $0.69 / 2.5$ & - & $4.08 / 14.6$ & $5.22 / 18.7$ & $9.08 / 32.63$ & $7.50 / 26.9$ \\
\hline 5 & $1.16 / 2.1$ & - & $0.80 / 1.4$ & $7.47 / 13.55$ & $8.77 / 15.9$ & $17.19 / 31.2$ & $19.71 / 35.8$ \\
\hline 6 & $0.99 / 1.6$ & - & $1.28 / 2.1$ & $7.96 / 13.2$ & $9.26 / 15.3$ & $18.94 / 31.2$ & $21.90 / 36.3$ \\
\hline 7 & $0.99 / 1.3$ & - & $2.45 / 3.2$ & $9.55 / 12.5$ & $10.80 / 14.2$ & $24.00 / 31.5$ & $28.40 / 37.3$ \\
\hline 8 & $0.71 / 0.8$ & - & $3.49 / 3.9$ & $10.79 / 12.2$ & $11.52 / 13.1$ & $29.48 / 33.4$ & $32.12 / 36.4$ \\
\hline $\begin{array}{c}\text { Comparison } \\
\text { East Balkhash }\end{array}$ & $0.96 / 1.37$ & - & $2.01 / 2.87$ & $8.94 / 12.8$ & $10.08 / 14.4$ & $22.42 / 32.1$ & $25.50 / 36.5$ \\
\hline & & & $0.66 / 1.3$ & $6.86 / 14.1$ & $7.68 / 15.7$ & $15.72 / 32.1$ & $26.50 / 33.8$ \\
\hline
\end{tabular}

\section{Practical part}

Process of sedimentation of calcium carbonates and magnesium of the water of Balkhash Lake is one of the factors which are constantly reducing the salt stock of the Lake, its mineralization and so is included in the used part of its salt balance.

In this connection research of the condition of carbonate and calcium balance in Balkhash Lake water in modern and long-term periods is of interest. The results of the calculation done by us for each hydrochemical area of the Lake (206 samples) during the summer period since 2009 are averaged and given in Table 6 and presented graphically on Figure 3 and 4.

Table 6: Characteristic of the condition of carbonate and calcium balance of the water of Balkhash Lake and the Ili River (August, 2009)

\begin{tabular}{|c|c|c|c|c|c|c|c|c|c|}
\hline \multirow{2}{*}{$\begin{array}{c}\text { No. } \\
\text { Area }\end{array}$} & \multirow{2}{*}{$\mathrm{t}^{\circ}, \mathrm{C}$} & $\mathrm{pH}$ & $\begin{array}{c}\mathrm{Ca}^{2+} \\
\mathrm{Mg} / 1\end{array}$ & \multirow{2}{*}{$\begin{array}{c}\mathrm{HCO}^{3-} \\
\mathrm{Mg} / 1\end{array}$} & \multicolumn{2}{|c|}{$\mathrm{CO}_{2}$} & \multirow{2}{\mathrm{CO}_{3}^{2-*}10-}{} & $\begin{array}{c}\mathrm{Ca}^{2+} * \\
\mathrm{CO}_{3}^{2-*} 10^{-9}\end{array}$ & $\begin{array}{c}\mathrm{S} / \\
\mathrm{SO}_{4}\end{array}$ \\
\hline 1 & 23.0 & 8.38 & 42.5 & 273.4 & 1.28 & 7.38 & 134.48 & 16.5 & 4.9 \\
\hline 2 & 23.0 & 8.47 & 39.5 & 266.7 & 1.12 & 6.12 & 171.17 & 20.0 & 6.0 \\
\hline
\end{tabular}


CBU INTERNATIONAL CONFERENCE ON INTEGRATION AND INNOVATION IN SCIENCE AND EDUCATION

\begin{tabular}{|c|c|c|c|c|c|c|c|c|c|}
\hline 3 & 23.6 & 8.48 & 36.2 & 294.7 & 1.03 & 7.18 & 213.51 & 19.4 & 5.8 \\
\hline 4 & 23.6 & 8.65 & 33.7 & 308.8 & 0.77 & 6.63 & 330.57 & 25.5 & 7.7 \\
\hline 5 & 24.1 & 8.80 & 23.4 & 452.5 & 0.69 & 7.83 & 742.50 & 3.2 & 9.1 \\
\hline 6 & 24.3 & 8.91 & 12.2 & 488.2 & 0.57 & 7.48 & 982.18 & 31.7 & 9.7 \\
\hline 7 & 24.2 & 9.00 & 19.2 & 587.6 & 0.58 & 9.30 & 1512.40 & 37.2 & 11.5 \\
\hline 8 & 24.8 & 9.05 & 13.6 & 654.7 & 0.56 & 8.34 & 2071.03 & 31.2 & 9.6 \\
\hline $\begin{array}{c}\text { Channel } \\
\text { River } \\
\text { Ili }\end{array}$ & 25.0 & 8.44 & 64.1 & 170.8 & 0.68 & 4.88 & 81.60 & 17.6 & 5.5 \\
\hline \multicolumn{7}{|l|}{ Source: Andasbayev \& Dzhetimov (2012) } \\
\hline \multicolumn{7}{|c|}{} \\
\hline
\end{tabular}

Figure 3: Change of value of mineralization of Balkhash Lake in its length

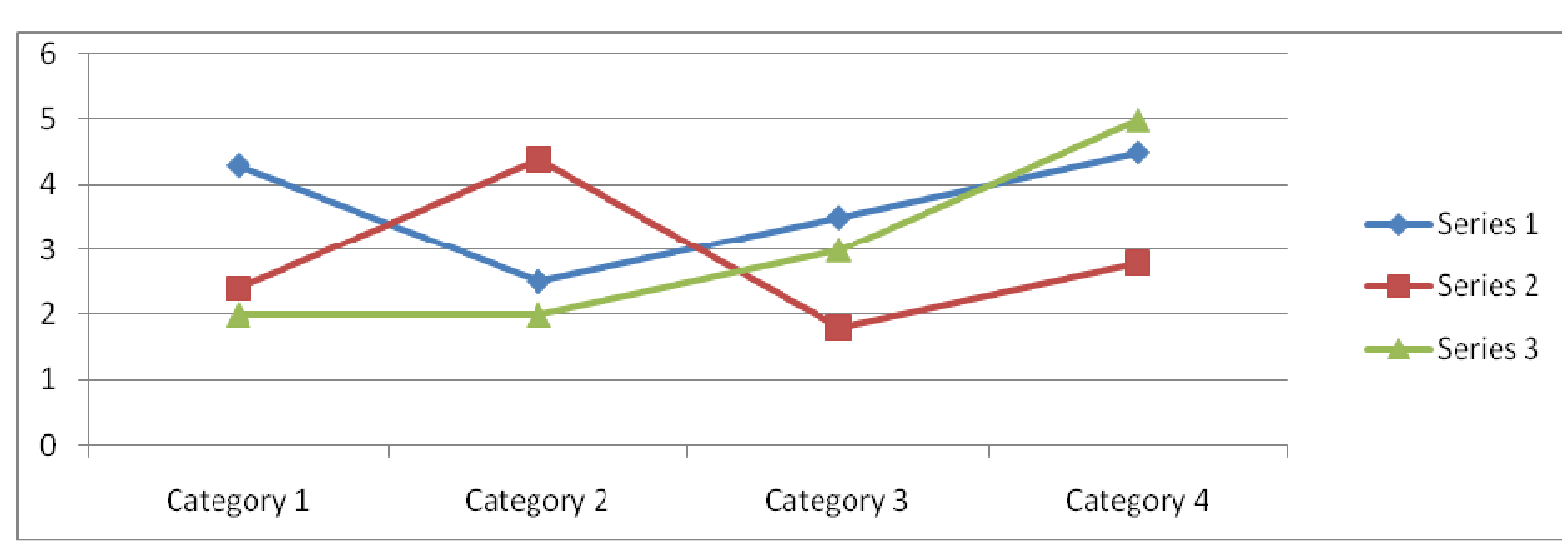

Source: Andasbayev \& Dzhetimov (2012)

Figure 4: Dependence of the content of carbonates and hydrocarbonates of calcium and magnesium on the value of mineralization of the water of Balkhash Lake (summer 2009)

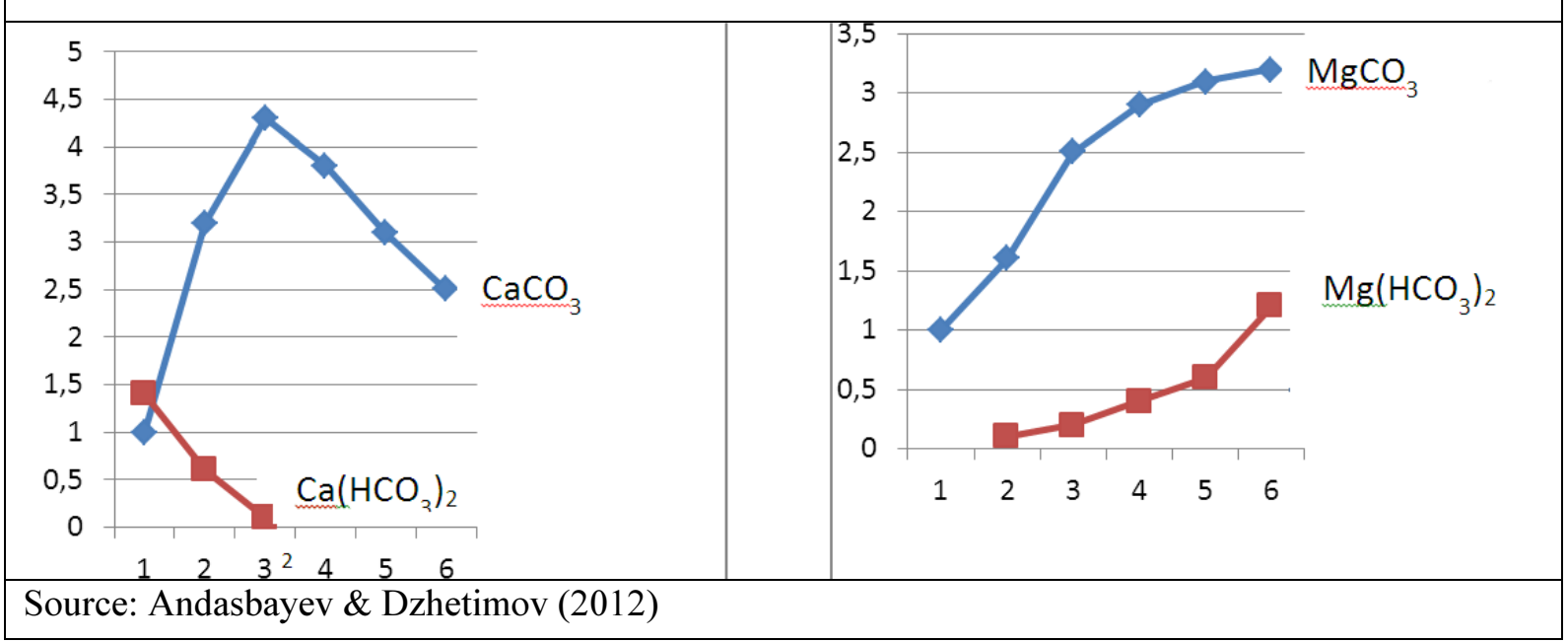

Apparently, the water of Balkhash Lake in its water area is oversaturated with carbonate of calcium, supersaturation is unequal and grows in the east direction from 3.6 to 15.2. Comparing average values of product of activity of $\mathrm{Ca}^{2+}$ and $\mathrm{CO}_{3}{ }^{2-}$ in the $1^{\text {st }}$ and the $8^{\text {th }}$ hydro chemical areas it is visible that they 
practically don't change: there is some increase of value $\mathrm{Ca}^{2+}+\mathrm{CO}_{3}{ }^{2-}$ from the $2^{\text {nd }}$ to the $6^{\text {th }}$ areas, then its decrease upon transition to the $7^{\text {th }}$ and the $8^{\text {th }}$ areas.

On Figure 1 and 2 there are also curves of changing of product of activities of ions of calcium and carbonate ions, the values of supersaturation in the water of Balkhash Lake received by different authors during 1985-2009.

Significant supersaturation of natural waters with carbonate of calcium is not infrequent phenomenon. So for example, in summer saturation of water with calcium carbonate exceeded the norm in the Kapchagaysky reservoir in 58 times, in some ponds of droughty zone - in 19 times, in lakes of the Bakhash-Alakol basin - in 3-9 times, in Issyk Lake - in 3-5 times, etc.

O.Alekin and N.Moricheva showed that the organic substance makes stabilizing impact on solutions oversaturated in relation to calcium carbonate (Alekin \& Morichev, 1961)

According to our research the permanganate oxidability of the water of Balkhash Lake increases from 7.89 in the western part to $10.0 \mathrm{mg} \mathrm{O} / 1$ in the eastern part.

The authors of this work did calculations of the quantity of carbonates fallen in the Lake for the period of 2009-2012. The results on ionic structure of the Ili River feeding Balkhash Lake are used for this purpose.

It appeared that the volume of carbonates from flow of salts during this period was $56 \%$ in average (Table 7).

Table 7: Average annual chemical composition of water of the Ili River

\begin{tabular}{|c|c|c|c|c|c|c|c|c|c|c|}
\hline \multirow{2}{*}{$\begin{array}{c}\text { Riv } \\
\text { er }\end{array}$} & \multirow[t]{2}{*}{ Years } & \multicolumn{6}{|c|}{ Ionic structure, $\mathrm{mg} / \mathrm{l}$} & \multirow[t]{2}{*}{$\begin{array}{c}\text { Sum of } \\
\text { ions of } \\
\mathrm{mg} / \mathrm{l}\end{array}$} & \multicolumn{2}{|c|}{$\begin{array}{c}\text { Carbonates } \\
\text { and hydro } \\
\text { carbonates } \\
\text { of Sa and } \\
\mathrm{Mg}\end{array}$} \\
\hline & & $\mathrm{Ca}^{2+}$ & $\mathrm{Mg}^{2+}$ & $\mathrm{Na}^{+}+\mathrm{K}^{+}$ & $\mathrm{HCO}_{3}{ }^{-}$ & $\mathrm{SO}_{4}{ }^{2-}$ & $\mathrm{Cl}^{-}$ & & $\mathrm{mg} / \mathrm{l}$ & $\%$ \\
\hline Ili & $1985-86$ & 41.0 & 10.5 & 8.5 & 144.0 & 30.4 & 9.2 & 244 & 188 & 77 \\
\hline & $2005-07$ & 42.0 & 23.0 & 50.0 & 198.0 & 91.0 & 24.0 & 428 & 255 & 59 \\
\hline & 2008-09 & 53.2 & 15.5 & 69.4 & 202.3 & 115.9 & 39.7 & 496 & 264 & 53 \\
\hline
\end{tabular}

Source: Andasbayev \& Dzhetimov (2012)

For clarification of regularities of continental salt formation isothermal evaporation in the laboratory environment of the water of Balkhash Lake was realized. It was established that the way of crystallization of salts at gradual concentrating of water differs from the order of salt extraction from waters of sea type. It is defined as it was specified above, by originality in the salts ratio: small content of sodium chloride (twice less than in sea water); high content of sodium sulfate; Balkhash water is rich in carbonate ions and magnesium ions. In this work the data on measuring ionic structure (the main salts) and some microelements of Balkhash water at isothermal evaporation at the stage of carbonates crystallization are provided (Table 8 ). Salt crystallization begins with calcium carbonate in 
the form of aragonite at total amount of salts of $16.6 \mathrm{~g} / \mathrm{l}$; the content $\mathrm{CaCO}_{3}$ reaches $110 \mathrm{mg} / \mathrm{l}$, in comparison with the initial one $-40 \mathrm{mg} / \mathrm{l}$. In process of aragonite fall, concentration of $\mathrm{CaCO}_{3}$ in the solution decreases at first, and then increases again.

Table 8: Results of the analysis of the samples selected in the course of isothermal $\left(25^{\circ} \mathrm{C}\right)$ evaporations of Balkhash water

\begin{tabular}{|c|c|c|c|c|c|c|c|c|c|c|}
\hline $\begin{array}{c}\text { Density } \\
\mathrm{g} / \mathrm{cm}^{3}\end{array}$ & $\mathrm{pH}$ & $\mathrm{CaCO}_{3}$ & $\mathrm{MgCO}_{3}$ & $\mathrm{Mg}\left(\mathrm{HCO}_{3}\right)_{2}$ & $\mathrm{MgSO}_{4}$ & $\mathrm{Na}_{2} \mathrm{SO}_{4}$ & $\mathrm{NaCl}$ & $\begin{array}{c}\text { Sum of } \\
\text { salts }\end{array}$ & Firm phase \\
\hline & \multicolumn{7}{|c|}{$\mathrm{mg} / 1$} & & \multicolumn{7}{|c|}{$\mathrm{g} / 1$} & \\
\hline 1.003 & 8.8 & 40.0 & 75.9 & 680.4 & 0.5 & 1.4 & 1.4 & 4.1 & - \\
\hline 1.014 & 9.2 & 70.0 & 375.5 & 651.4 & 1.4 & 2.2 & 2.9 & 7.7 & - \\
\hline 1.015 & 9.2 & 85.0 & 750.9 & 834.0 & 2.1 & 4.2 & 4.8 & 12.9 & - \\
\hline 1.013 & 9.2 & 110.1 & 1426.0 & 702.3 & 1.9 & 6.5 & 5.8 & 16.6 & \\
\hline 1.024 & 9.4 & 105.1 & 2236.0 & 1053.5 & 3.5 & 10.4 & 9.9 & 27.2 & Nesquehonite \\
\hline 1.021 & 9.4 & 50.0 & 1134.0 & 1675.3 & 4.7 & 11.5 & 9.1 & 28.2 & \\
\hline 1.032 & 9.4 & 115.1 & 2636.8 & 556.0 & 4.8 & 9.1 & 12.2 & 29.2 & aragonite \\
\hline 1.097 & 9.4 & 185.1 & 1531.5 & 1960.7 & 18.6 & 12.1 & 36.7 & 71.1 & Nesquehonite \\
\hline & & & & & & & & & $\begin{array}{c}\text { Main } \\
\text { magnesium } \\
\text { carbonate }\end{array}$ \\
1.095 & 9.0 & 155.1 & 3143.1 & 2136.3 & 16.1 & 46.6 & 45.9 & 114.0 \\
\hline
\end{tabular}

When general mineralization reaches $27.2 \mathrm{~g} / \mathrm{l}$ aragonite $\left(\mathrm{CaCO}_{3}\right)$ is joined by nesquehonite $\left(\mathrm{MgCO}_{3} * 3 \mathrm{H}_{2} \mathrm{O}\right)$. The content of $\mathrm{MgCO}_{3}$ in the solution, increased to $2.2 \mathrm{~g} / \mathrm{l}$, decreases in 2 times (from 2.2 to $1.1 \mathrm{~g} / \mathrm{l}$ ). At general stock of carbonates about $5.4 \mathrm{~g} / 1$ instead of good crystals of nesquehonite the main magnesium carbonate $\left(3 \mathrm{MgCO}_{3} * \mathrm{Mg}(\mathrm{OH})_{2} * 3 \mathrm{H}_{2} \mathrm{O}\right)$ settles down in the form of microcrystalline almost amorphous mass. After that the growth rate of concentration of carbonates decreases. Sparingly soluble salts are replaced by well soluble sulfates and chlorides of sodium and magnesium. The behavior of potassium in the course of isothermal evaporation of Balkhash water was studied. Data available in literature concern generally potassium distribution at concentrating of sea type waters or analysis of data in content of potassium in waters with different mineralization.

Earlier we ascertained that the content of potassium in solution increases with growth of general mineralization, excluding the stage of carbonates sedimentation. At the beginning of evaporation (Table 9) concentration of potassium increases in the liquid phase in 61 times (from 3 to $185 \mathrm{mg} / \mathrm{l}$ ).

Table 9: Change of the content of potassium in the course of isothermal evaporation of the water of Balkhash Lake

\begin{tabular}{|c|c|c|c|}
\hline $\begin{array}{c}\text { Content of } \\
\text { potassium, } \mathrm{mg} / \mathrm{l}\end{array}$ & $\begin{array}{c}\text { Content of chlorine, } \\
\mathrm{mg} / \mathrm{l}\end{array}$ & $\begin{array}{c}\text { Sum of salts } \\
\%\end{array}$ & $\mathrm{~K} * 103 / \mathrm{Cl}^{-}$ \\
\hline 3 & 0.9 & 0.4 & 3.5 \\
\hline 135 & 1.0 & 0.4 & 123.2 \\
\hline 150 & 1.3 & 0.5 & 105.8 \\
\hline 185 & 1.8 & 0.7 & 93.6 \\
\hline 147 & 1.5 & 0.7 & 88.7 \\
\hline 202 & 1.9 & 0.9 & 89.8 \\
\hline 400 & 4.3 & 1.9 & 82.1 \\
\hline 525 & 5.4 & 2.7 & 85.4 \\
\hline
\end{tabular}


CBU INTERNATIONAL CONFERENCE ON INTEGRATION AND INNOVATION IN SCIENCE AND EDUCATION

\begin{tabular}{|c|c|c|c|}
\hline 837 & 8.5 & 3.6 & 85.7 \\
\hline 1437 & 13.7 & 5.3 & 85.6 \\
\hline 2632 & 25.4 & 10.4 & 86.1 \\
\hline 4125 & 37.9 & 14.9 & 87.5 \\
\hline \multicolumn{4}{|l}{} \\
\hline
\end{tabular}

\section{Analysis and discussion}

The results of the experiments (Table 10) showed that in saturated carbonates solutions there is an increase of potassium ions to sediment, and in the increased concentration areas absorption decreases from $200-400 \mathrm{mg} / \mathrm{l}$. In very diluted solutions absorption of potassium ions is observed. It is necessary to note that $\mathrm{CaCO}_{3}$ in the firm phase has more absorbing ability than $\mathrm{MgCO}_{3}$, and according to the crystal and optical analysis the presence of potassium ions in the sediment does not change the structure of the latter. Joint sedimentation of potassium is observed also at isothermal evaporation $\left(25^{\circ} \mathrm{C}\right)$ of the mixture of potassium carbonate solutions with saturated solution of calcium carbonate, and also potassium sulfate with saturated solution of calcium sulfate (Andasbayev \& Dzhetimov, 2012) (Table 11).

Table 10: Absorption of potassium ions by calcium and magnesium carbonates, experiments results

\begin{tabular}{|c|c|c|c|c|c|c|c|}
\hline \multirow[t]{2}{*}{ Sample } & \multicolumn{2}{|c|}{$\begin{array}{l}\text { Content in solution, } \\
\mathrm{mg} / \mathrm{l}\end{array}$} & \multirow{2}{*}{$\begin{array}{l}\text { The absorbed } \\
\text { potassium, \% }\end{array}$} & \multirow[t]{2}{*}{ Sample } & \multicolumn{2}{|c|}{$\begin{array}{c}\text { Content in } \\
\text { solution, } \mathrm{mg} / 1\end{array}$} & \multirow{2}{*}{$\begin{array}{c}\text { Absorbed } \\
\text { potassium } \\
{[\%]}\end{array}$} \\
\hline & $\mathrm{K}^{+}$ & $\mathrm{Ca}^{+}$ & & & $\mathrm{K}^{+}$ & $\mathrm{Ca}^{+}$ & \\
\hline 1 & 2 & 3 & 4 & 5 & 6 & 7 & 8 \\
\hline \multicolumn{4}{|c|}{ Solution $\mathrm{K}_{2} \mathrm{CO}_{3}+$ sediment $\mathrm{CaCO}_{3}$} & \multicolumn{4}{|c|}{ Solution $\mathrm{K}_{2} \mathrm{CO}_{3}+$ sediment $\mathrm{MgCO}_{3}$} \\
\hline Starting & 4.0 & - & - & starting & 7.2 & - & - \\
\hline Contact & 4.3 & 10.4 & - & contact & 7.4 & 40.1 & - \\
\hline Starting & 15.0 & - & - & starting & 18.0 & - & - \\
\hline Contact & 15.5 & 11.5 & - & contact & 18.0 & 42.5 & - \\
\hline Starting & 61.0 & - & - & starting & 56.0 & - & - \\
\hline Contact & 53.0 & 5.4 & 13.1 & contact & 58.0 & 36.5 & - \\
\hline 1 & 2 & 3 & 4 & 5 & 6 & 7 & 8 \\
\hline Starting & 70.0 & - & - & starting & 185.0 & - & - \\
\hline Contact & 47.0 & 8.5 & 32.8 & contact & 185.0 & 27.9 & - \\
\hline Starting & 200.0 & - & - & starting & 360.0 & - & - \\
\hline Contact & 183.0 & 0.6 & 8.5 & contact & 360.0 & 25.5 & - \\
\hline Starting & 450.0 & - & - & starting & 635.0 & - & - \\
\hline Contact & 425.0 & 0.6 & 5.5 & contact & 635.0 & 20.6 & - \\
\hline Starting & 690.0 & - & - & starting & 750.0 & - & - \\
\hline Contact & 660.0 & 0.6 & 4.3 & contact & 720.0 & 3.3 & - \\
\hline starting & 860.0 & - & - & starting & 825.0 & 23.1 & 3.0 \\
\hline Contact & 840.0 & 0.6 & 2.3 & contact & 800.0 & 23.1 & 3.0 \\
\hline \multicolumn{4}{|c|}{ Solution $\mathrm{KCl}+$ sediment $\mathrm{CaCO}_{3}$} & \multicolumn{4}{|c|}{ Solution $\mathrm{KC} 1+$ sediment $\mathrm{MgCO}_{3}$} \\
\hline starting & 4.3 & - & - & starting & 9.0 & - & - \\
\hline Contact & 4.3 & 10.2 & - & contact & 9.0 & 37.7 & - \\
\hline starting & 19.0 & - & - & starting & 12.0 & - & - \\
\hline Contact & 18.5 & 6.1 & 2.6 & contact & 12.0 & 37.7 & - \\
\hline starting & 67.0 & - & - & starting & 62.0 & - & - \\
\hline Contact & 58.0 & 7.0 & 13.4 & contact & 62.0 & 36.4 & - \\
\hline starting & 166.0 & - & - & starting & 240.0 & - & - \\
\hline
\end{tabular}


CBU INTERNATIONAL CONFERENCE ON INTEGRATION AND INNOVATION IN SCIENCE AND EDUCATION

\begin{tabular}{|l|c|c|c|l|c|c|c|}
\hline Contact & 140.0 & 8.7 & 15.6 & contact & 240.0 & 36.4 & - \\
\hline starting & 400.0 & - & - & starting & 320.0 & - & - \\
\hline Contact & 380.0 & 11.5 & 5.0 & contact & 320.0 & 38.9 & - \\
\hline starting & 690.0 & - & - & starting & 660.0 & - & - \\
\hline Contact & 670.0 & 11.5 & 2.8 & contact & 630.0 & 42.5 & 4.5 \\
\hline
\end{tabular}

Table 11: The results of experiments on isothermal evaporation of solutions of potassium and calcium salts

\begin{tabular}{|c|c|c|c|}
\hline $\begin{array}{c}\text { Content of } \mathrm{K} \\
\text { in solution } \\
\mathrm{mg} / \mathrm{l}\end{array}$ & $\begin{array}{c}\text { Content of } \mathrm{Ca} \\
\text { in solution } \\
\mathrm{mg} / \mathrm{l}\end{array}$ & $\begin{array}{c}\text { Absorbed } \\
\text { potassium, } \%\end{array}$ & $\begin{array}{c}\text { Firm } \\
\text { phase }\end{array}$ \\
\hline \multicolumn{4}{|c|}{ solution $\mathrm{K}_{2} \mathrm{CO}_{3}+\mathrm{CaCO}_{3}$} \\
\hline 700.0 & 8.0 & - & Aragonite \\
600.0 & 6.6 & 14.0 & - \\
\hline \multicolumn{4}{|c|}{ Solution $\mathrm{K}_{2} \mathrm{SO}_{4}+\mathrm{Ca} \mathrm{SO}_{4}$} \\
\hline 537.0 & 521.0 & - & - \\
760.0 & 751.5 & - & gypsum \\
600.0 & 666.3 & 21.0 & \\
\hline
\end{tabular}

\section{Conclusion}

On the basis of the made experiments it is possible to make a conclusion that one of the main responsible things in joint potassium sedimentation are carbonate and calcium sulfate and in less measure magnesium and calcium carbonates.

The great value for diagnostics of deposit represents distribution of microelements in natural waters among which the special place is taken by boron. The behavior of boron in the course of evaporation of sea water and the solutions imitating sea water is studied rather well, but there are no data in this relation for waters of continental origin (Beremzhanov \& Bolibok, 1986).

Evaporating Balkhash water it was interesting to observe boron distribution between the firm and liquid phases. Proceeding from the received data presented in Table 12, you can see that boron behaves at evaporation of Balkhash water similar to change of potassium concentration. Its content in the liquid phase increases in the beginning from 1.8 to $5.6 \mathrm{mg} / \mathrm{l}$, and then a half of the boron content falls out together with carbonates. The values of boron-chloric coefficients decrease up to 3.0.

Table 12: Change of the boron content in the course of isothermal evaporation of the water of Balkhash Lake

\begin{tabular}{|c|c|c|c|}
\hline $\begin{array}{c}\text { Content of boron, } \\
\mathrm{mg} / \mathrm{l}\end{array}$ & $\begin{array}{c}\text { Content of chlorine, } \\
\mathrm{mg} / \mathrm{l}\end{array}$ & $\mathrm{B} * 10 / \mathrm{Cl}^{-}$ & $\begin{array}{c}\text { Sum of } \\
\text { salts, } \%\end{array}$ \\
\hline 1.8 & 0.8 & 2.9 & 0.3 \\
\hline 5.6 & 1.2 & 14.9 & 0.5 \\
\hline 2.3 & 1.3 & 5.8 & 0.5 \\
\hline 2.9 & 1.8 & 10.2 & 0.7 \\
\hline
\end{tabular}




\begin{tabular}{|c|c|c|c|}
\hline 2.7 & 2.9 & 3.0 & 1.3 \\
\hline 8.0 & 5.9 & 4.3 & 2.6 \\
\hline 10.4 & 6.5 & 5.1 & 2.9 \\
\hline 19.5 & 11.6 & 5.3 & 3.9 \\
\hline 27.0 & 13.7 & 5.8 & 5.3 \\
\hline 43.0 & 25.4 & 5.1 & 10.4 \\
\hline 67.5 & 37.9 & 5.2 & 14.9 \\
\hline \multicolumn{2}{|l}{} \\
\hline
\end{tabular}

In the solutions of boric acid being in contact with the firm phase in the form of aragonite and the main magnesium carbonate (Table 12) decrease in boron concentration is observed. All this says that boron as isomorphic impurity is entrained to the sediment with calcium and magnesium carbonates. It is favoured by the fact that the ionic radius of complex ion $\mathrm{BO}_{3}{ }^{3-}$ in which form boron the most often appears in natural waters equals to 0.136 , and at $\mathrm{CO}_{3}{ }^{2-}$ it equals to 0.129 that is $4 \%$ higher, but as borate ion has a bigger charge, this discrepancy is compensated.

\section{References}

Abrosov, V. N. (1983). Ozero Balhash [Balkhash Lake]. Leningrad, Russia, Nauka.

Alekin, O. A. \& Morichev, N. P. (1961). Izmenenie nassyshhennosti karbonatom kalcia rechnoi vody pri smeshenii eio s morskoi vodoi [Change of saturation with calcium carbonate of river water at its mixture with sea water]. Gidrohimicheskie materially [Hydrochemical materials], 31, pp. 95-107. Novosibirsk, Russia: Kniga.

Andasbayev, E. \& Dzhetimov, M. (2012). Fizicheskoje i himicheskoje issledovanie processov soleobrazovanija v vode ozera Balhash [Physical and chemical research of processes of salt formation in the water of Balkhash Lake]. Taldykorgan, Kazakhstan: Lazer. ISBN 9864-2.

Beremzhanov, B. A. \& Bolibok, S. S. (1986). Povedenie broma, ioda i bora v processe isotermicheskogo isparenija kontinentalnyh vod [Behavior of bromine, iodine and boron in the course of isothermal evaporation of continental waters]. Journal Himija i himicheskaja tehnologija [Chemistry and chemical technology], 16, pp. 5-10. Almaty, Kazakhstan, Jestestvoznanie.

Beremzhanov, B. A. (1989). Soleobrazovanie v nekotoryh kontinentalnyh basseinah Kazahstana. [Formation of salts in some continental basins of Kazakhstan]. Almaty, Kazakhstan: Kniga.

Dostay, Z. (2005). Nauchnaja osnova upravlenija gidro-ekologicheskim sostojanijem drenazhnyh basseinov v Centralnoi Azii [Scientific basis for management of hydro-ecological condition of drainage basins in Central Asia]. Almaty, Kazakhstan: Isskustvo.

Moon, A. I. \& Bekturova, A. B. (1992). Raspredelenie mikroelementov v vodoiomah Kazahstana. [Distribution of microelements in reservoirs of Kazakhstan]. Almaty, Kazakhstan: Nauka.

Moore, J. \& Ramamurti, S. (2010). Tjazholye metally v prirodnyh vodah [Heavy metals in natural waters]. Moscow, Russia: Mir.

Tarasov, M. N. (1961). Gidrohimia ozera Balhash [Hydrochemistry of Balkhash Lake]. Moscow, Russia: Academy of Sciences of the USSR. 